\title{
From pole to pole: 33 years of physical oceanography onboard R/V Polarstern
}

\author{
Amelie Driemel $^{1}$, Eberhard Fahrbach ${ }^{1, \dagger}$, Gerd Rohardt $^{1}$, Agnieszka Beszczynska-Möller $^{2}$, \\ Antje Boetius ${ }^{1}$, Gereon Budéus ${ }^{1}$, Boris Cisewski ${ }^{4}$, Ralph Engbrodt ${ }^{3}$, Steffen Gauger ${ }^{3}$, Walter Geibert ${ }^{1}$, \\ Patrizia Geprägs $^{5}$, Dieter Gerdes ${ }^{1}$, Rainer Gersonde ${ }^{1}$, Arnold L. Gordon ${ }^{6}$, Hannes Grobe ${ }^{1}$, \\ Hartmut H. Hellmer ${ }^{1}$, Enrique Isla ${ }^{7}$, Stanley S. Jacobs ${ }^{6}$, Markus Janout ${ }^{1}$, Wilfried Jokat ${ }^{1}$, \\ Michael Klages $^{8}$, Gerhard Kuhn ${ }^{1}$, Jens Meincke ${ }^{9, *}$, Sven Ober ${ }^{10}$, Svein Østerhus ${ }^{11}$, Ray G. Peterson ${ }^{12, \dagger}$, \\ Benjamin Rabe ${ }^{1}$, Bert Rudels ${ }^{13}$, Ursula Schauer ${ }^{1}$, Michael Schröder ${ }^{1}$, Stefanie Schumacher ${ }^{1}$, \\ Rainer Sieger ${ }^{1}$, Jüri Sildam ${ }^{14}$, Thomas Soltwedel ${ }^{1}$, Elena Stangeew ${ }^{3}$, Manfred Stein ${ }^{4}{ }^{*}$, Volker H Strass ${ }^{1}$, \\ Jörn Thiede ${ }^{1, *}$, Sandra Tippenhauer ${ }^{1}$, Cornelis Veth ${ }^{10, *}$, Wilken-Jon von Appen ${ }^{1}$, Marie-France Weirig ${ }^{3}$, \\ Andreas Wisotzki ${ }^{1}$, Dieter A. Wolf-Gladrow ${ }^{1}$, and Torsten Kanzow ${ }^{1}$ \\ ${ }^{1}$ Alfred-Wegener-Institut Helmholtz-Zentrum für Polar- und Meeresforschung, Bremerhaven, Germany \\ ${ }^{2}$ Institute of Oceanography Polish Academy of Science, Sopot, Poland \\ ${ }^{3}$ independent researcher \\ ${ }^{4}$ Thünen-Institut: Seefischerei, Hamburg, Germany \\ ${ }^{5}$ MARUM - Zentrum für Marine Umweltwissenschaften, Bremen, Germany \\ ${ }^{6}$ Lamont-Doherty Earth Observatory, Columbia University, New York, NY, USA \\ ${ }^{7}$ Institute of Marine Sciences-CSIC, Barcelona, Spain \\ ${ }^{8}$ University of Gothenburg, Department of Marine Sciences, Gothenburg, Sweden \\ ${ }^{9}$ Institut für Meereskunde, Hamburg, Germany \\ ${ }^{10}$ Royal Netherlands Institute for Sea Research, 't Horntje, the Netherlands \\ ${ }^{11}$ Uni Research Climate, Bergen, Norway \\ ${ }^{12}$ Scripps Institution of Oceanography, UC San Diego, USA \\ ${ }^{13}$ University of Helsinki, Helsinki, Finland \\ ${ }^{14}$ Centre for Maritime Research and Experimentation, La Spezia, Italy \\ *retired \\ $\dagger$ deceased \\ Correspondence to: Gerd Rohardt (Gerd.Rohardt@awi.de)
}

Received: 16 December 2016 - Discussion started: 22 December 2016

Revised: 21 February 2017 - Accepted: 21 February 2017 - Published: 21 March 2017

\begin{abstract}
Measuring temperature and salinity profiles in the world's oceans is crucial to understanding ocean dynamics and its influence on the heat budget, the water cycle, the marine environment and on our climate. Since 1983 the German research vessel and icebreaker Polarstern has been the platform of numerous CTD (conductivity, temperature, depth instrument) deployments in the Arctic and the Antarctic. We report on a unique data collection spanning 33 years of polar CTD data. In total 131 data sets (1 data set per cruise leg) containing data from 10063 CTD casts are now freely available at doi:10.1594/PANGAEA.860066. During this long period five CTD types with different characteristics and accuracies have been used. Therefore the instruments and processing procedures (sensor calibration, data validation, etc.) are described in detail. This compilation is special not only with regard to the quantity but also the quality of the data - the latter indicated for each data set using defined quality codes. The complete data collection includes a number of repeated sections for which the quality code can be used to investigate and evaluate long-term changes. Beginning with 2010, the salinity measurements presented here are of the highest quality possible in this field owing to the introduction of the OPTIMARE Precision Salinometer.
\end{abstract}




\section{Introduction}

Our oceans are always in motion - huge water masses are circulated not only by winds but also by global seawater density gradients. These gradients result from differences in water temperatures and salinities and the water movement transports heat, oxygen, $\mathrm{CO}_{2}$, and nutrients among latitudes (Stewart, 2009). Measuring the ocean's temperature and salinity is therefore essential not only to understand the ecology of the world oceans but also the influence of the oceans on our climate.

According to Stewart (2009) the first water samples from depths down to around $1600 \mathrm{~m}$ were taken in the tropical Atlantic aboard the Earl of Hallifax in 1750/1751 with a special bucket and a thermometer (Hales, 1751). Even then, the results (a stable cold water layer beneath the warm surface) hinted at an inflow of deep water from the polar regions (Stewart, 2009). Until the 1970s, measurements of ocean temperatures and salinities were conducted primarily using reversing mercury thermometers and Nansen water bottles (Warren, 2008). Due to the usually limited number of Nansen bottles and thermometers on board, the number of depth levels which could be sampled was also limited, which resulted in a rather coarse vertical resolution of temperature and salinity. With the development of submersible electrical instruments for temperature and salinity (conductivity) measurements in the 1950s, high-resolution measurements of temperature and salinity profiles became possible (Brown, 1991; Stewart, 2009). During the 1970s and 80s, the use of CTDs (conductivity, temperature, depth instruments) replaced the formerly used method almost completely. Numerous manufacturers produced a variety of sensors and instruments. For example, in 1974 Neil Brown formed Neil Brown Instrument Systems, Inc. and manufactured the Mark III CTD ${ }^{1}$ (Brown, 1991).

$\mathrm{R} / \mathrm{V}$ Polarstern is a research icebreaker operated by the Alfred Wegener Institute (AWI) in Bremerhaven (Germany), which has operated since 1982 in Antarctica (austral summer) and the Arctic (northern summer) ${ }^{2}$. The first CTD used on Polarstern was the aforementioned Neil Brown, Mark IIIB CTD. It was deployed for the first time on cruise leg ANT-II/3, during the ship's second trip to Antarctica in November/December 1983. This giant step for AWI oceanographers, which was supervised by Gerd Rohardt (Rohardt, 2010a), ended abruptly when that same probe accidentally "flew" overboard a month later during ANT-II/4. Despite many efforts to regain it, the probe was lost, which is why the respective data set of this leg (Rohardt, 2010b) contains CTD as well as Nansen-bottle-derived data. The latter

\footnotetext{
${ }^{1}$ Later it was manufactured by EG\&G Ocean Instruments and after that by General Oceanics.

${ }^{2}$ See also the description in Driemel et al. (2016) about Polarstern history and cruise characteristics.
}

was only possible due to the fact that guest researcher Manfred Stein (Institut für Seefischerei, Hamburg) had brought Nansen bottles and reversing thermometers as a backup for his ME-OTS-CTD on board during leg ANT-II/2 (no data). This anecdote clearly demonstrates that 1983 was still a transition period for hydrographic observations to electronic devices.

Despite this rather unfortunate start, a Neil Brown, Mark IIIB CTD was successfully used on Polarstern until 1996. Starting in 1992, a Sea-Bird SBE 911plus CTD was in use by Kees Veth (Royal Netherlands Institute for Sea Research, data included here). A year later, Gereon Budéus was the first AWI researcher to use the SBE 911plus on Polarstern, testing the behavior of the probe in cold conditions. The instrument has been used routinely on Polarstern since then, in parallel with Neil Brown equipment. On four cruise legs (1995-1999) Polarstern was equipped with the direct successor of the Mark IIIB, called the ICTD and manufactured by Falmouth Scientific. Additionally, during two legs (1986-1987), guest researchers deployed a ME-OTS-CTD. The SEA-BIRD SBE 911plus is probably the most widely used CTD type currently, and has been the only type used on Polarstern since 1999 (see also Fig. 1).

In the following, we describe a data compilation of 33 years (1983-2016) of CTD measurements from R/V Polarstern. In Sect. 2 we provide details on the CTD types used, the parameters measured, and on data processing. A focus is set on the improvement of the salinity measurements over time and the reasons thereof. In Sect. 3 we describe the data sets in respect to composition, extent, access, and quality.

\section{Methods}

A CTD directly measures conductivity, temperature, and pressure of water during its down- and up-cast, resulting in a profile from the water surface to the bottom and back. Derived variables are salinity, density, and water depth. The CTDs onboard Polarstern were typically deployed in combination with a water sampler construction, holding 12, 24, or 36 bottles (named rosette or carousel, depending on the manufacturer; see Fig. 2). The CTD is mounted inside the frame of the water sampler in a way that the sensors measure the undisturbed water during the down-cast. The down-cast CTD profile is displayed on board in realtime to allow the CTD operator to choose the water layers from which water samples for subsequent chemical and biological analyses are to be taken during the up-cast.

Due to the mounting technique, the measurements taken during the up-cast are not from undisturbed water but are influenced by water parcels from deeper layers which are dragged upwards by the CTD/rosette. Therefore, mostly only 


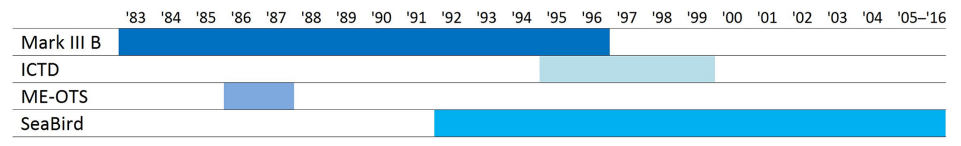

Figure 1. Overview of the period of deployment of different CTD types onboard Polarstern, with first line denoting the years. Sea-Bird CTD sondes were here combined into a single bar.

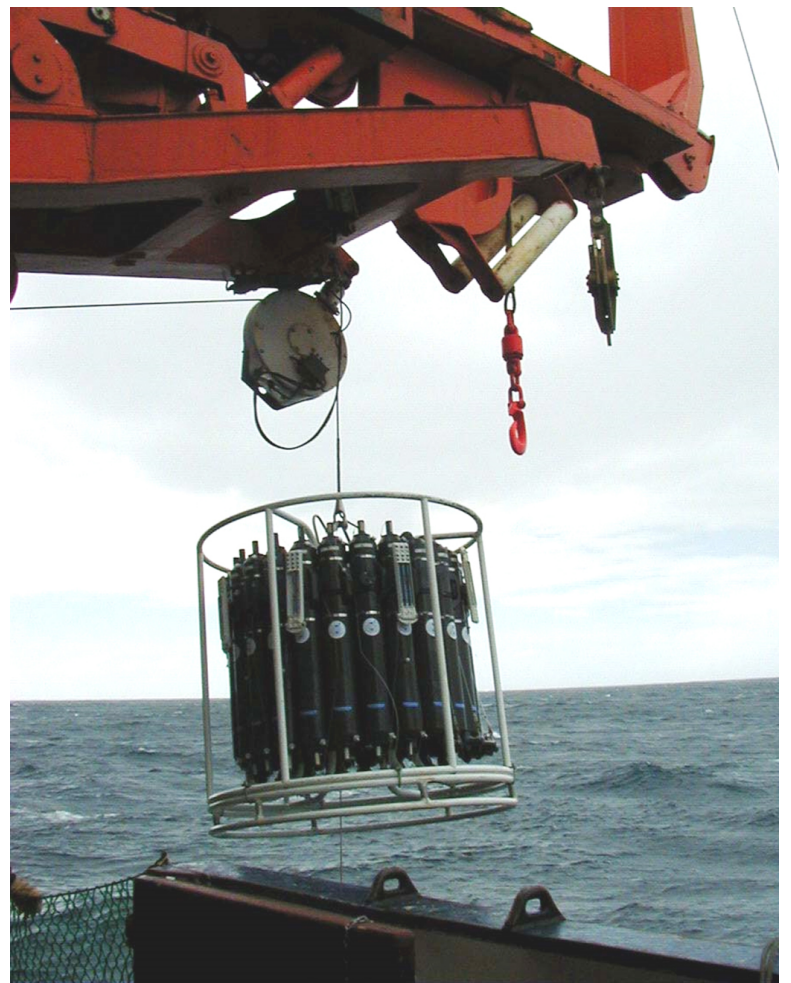

Figure 2. Picture of a typical CTD/rosette system used by the Alfred Wegener Institute (picture by Gerd Rohardt).

the down-cast CTD profile is used and archived (for details, see Sect. 2.5).

\subsection{Instruments and specifications}

Five different CTD types have been used onboard Polarstern from 1983 until the present. As the instruments have changed, so have the range, accuracy, stability, resolution, and response of the sensors. Table 1 shows in detail the manufacturers' specifications of the instruments, and the periods of use are shown in Fig. 1 (Sea-Bird probes combined). The table also indicates the accuracy limits officially adopted for the World Ocean Circulation Experiment (WOCE). Using the OPTIMARE Precision Salinometer (OPS) has provided accuracies even better than those required by WOCE (see Sect. 2.6). However, we would like to stress here that regular servicing and calibration is required to keep the instrument at least within the accuracy given by the manufacturer.

\subsection{Laboratory calibration of instruments}

In order to obtain precise hydrographic data, frequent calibrations of the sensors and careful inspection and preparation of the instruments (CTD, water sampler and bottles) is necessary. From 1983 until 1986, Neil Brown Mark IIIB CTDs were calibrated by the manufacturer. Each sensor had its own electronic board with the calibration stored on it. Changing a sensor thus required installing the corresponding electronic board as well. When Ray Weiss from Scripps Institution of Oceanography (SIO) participated on Polarstern cruise ANT$\mathrm{V} / 3$ in 1986, he suggested including the AWI-CTDs into the SIO calibration process. Since that time, the AWI-CTDs have been calibrated by SIO before and after each campaign. The first calibration revealed that the AWI Mark IIIB showed the same behavior as the SIO Mark IIIB: (a) the pressure sensor showed strong hysteresis depending on the maximum pressure and (b) the temperature readout showed a step-like discontinuity near $0{ }^{\circ} \mathrm{C}$ which further depended on the direction of the temperature change, i.e., whether the temperature increased or decreased (R. Williams, SIO, personal communication, 1986). Because a temperature correction of such a behavior is fairly complicated, a few years later SIO modified the electronic boards, shifting the discontinuity from about 0 to $+3{ }^{\circ} \mathrm{C}$.

The Falmouth Triton ICTDs from AWI were also shipped to SIO for calibration. This continued support made the change from Mark IIIB to ICTD much easier, and underlined the advantages of the new instrument: the SIO calibration confirmed that the pressure showed negligible levels of hysteresis and that the temperature correction was only small, with no stepwise behavior from -2 to $30^{\circ} \mathrm{C}$.

The long lasting collaboration between AWI and the calibration laboratory of SIO ended after completely switching over to Sea-Bird SBE911plus because Sea-Bird Electronics themselves performed high-level calibration of their instruments. In general, ever since the SBE 911plus was introduced, the CTD operators' job on board became much easier. The SBE 911plus featured dual sensors (two for both temperature and conductivity) and software, which displayed the sensor differences. This allowed identifying and changing sensors which became faulty. Replacing faulty sensors early prevents losing valuable data. With the introduction of dual sensors and the use of special software, in situ calibrations were still executed (see Sect. 2.4), but the number of samples could be reduced. 
Table 1. Sensor types and the manufacturers' specifications of CTDs used on board Polarstern.

\begin{tabular}{|c|c|c|c|c|c|}
\hline $\begin{array}{l}\text { Instrument and } \\
\text { manufacturer }\end{array}$ & $\begin{array}{l}\text { Period } \\
\text { of use }\end{array}$ & Specifications & Pressure & Temperature & Conductivity \\
\hline & & $\begin{array}{l}\text { WOCE accuracy } \\
\text { limits }\end{array}$ & $\pm 3 \mathrm{dbar}$ & $\pm 0.001{ }^{\circ} \mathrm{C}$ & $\pm 0.003 \mathrm{mS} \mathrm{cm}^{-1}$ \\
\hline $\begin{array}{l}\text { Multisonde* } \\
\text { ME-OTS-CTD } \\
\text { Meerestechnik } \\
\text { Elektronik, } \\
\text { Trappenkamp }\end{array}$ & $\begin{array}{l}1986 \\
\text { to } \\
1987\end{array}$ & $\begin{array}{l}\text { Sensor: } \\
\text { Range: } \\
\text { Accuracy: } \\
\text { Stability: } \\
\text { Resolution: } \\
\text { Response: }\end{array}$ & $\begin{array}{l}\text { Strain gauge bridge } \\
0 \text { to } 6000 \text { dbar } \\
0.35 \% \text { f.s. } \\
- \\
0.2 \mathrm{dbar} \\
-\end{array}$ & $\begin{array}{l}\text { Platinum resistance } \\
-2 \text { to } 35^{\circ} \mathrm{C} \\
\pm 0.005^{\circ} \mathrm{C} \\
\pm 0.001{ }^{\circ} \mathrm{C} \text { month }^{-1} \\
0.001{ }^{\circ} \mathrm{C} \\
60 \mathrm{~ms}\end{array}$ & $\begin{array}{l}\text { Symmetric electrode cell } \\
5 \text { to } 55 \mathrm{mS} \mathrm{cm}^{-1} \\
\pm 0.005 \mathrm{mS} \mathrm{cm}^{-1} \\
0.002 \mathrm{mS} \mathrm{cm}^{-1} \text { month }^{-1} \\
0.001 \mathrm{mS} \mathrm{cm}^{-1} \\
-\end{array}$ \\
\hline $\begin{array}{l}\text { Mark IIIB } \\
\text { Neil Brown } \\
\text { Instruments } \\
\text { later: EG\&G } \\
\text { Marine Instruments/ } \\
\text { General Oceanics }\end{array}$ & $\begin{array}{l}1983 \\
\text { to } \\
1996\end{array}$ & $\begin{array}{l}\text { Sensor: } \\
\text { Range: } \\
\text { Accuracy: } \\
\text { Stability: } \\
\text { Resolution: } \\
\text { Response: }\end{array}$ & $\begin{array}{l}\text { Strain gauge bridge } \\
0 \text { to } 6500 \mathrm{dbar} \\
\pm 6.5 \mathrm{dbar} \\
0.1 \% \text { month }^{-1} \\
0.1 \mathrm{dbar} \\
-\end{array}$ & $\begin{array}{l}\text { Platinum Thermistor } \\
-3 \text { to } 32^{\circ} \mathrm{C} \\
\pm 0.005^{\circ} \mathrm{C} \\
0.001{ }^{\circ} \mathrm{C} \text { month }^{-1} \\
0.0005^{\circ} \mathrm{C} \\
-\end{array}$ & $\begin{array}{l}\text { Four-electrode cell } \\
1 \text { to } 65 \mathrm{mS} \mathrm{cm}^{-1} \\
\pm 0.005 \mathrm{mS} \mathrm{cm}^{-1} \\
0.003 \mathrm{mS} \mathrm{cm}^{-1} \text { month }^{-1} \\
0.001 \mathrm{mS} \mathrm{cm}^{-1} \\
-\end{array}$ \\
\hline $\begin{array}{l}\text { Triton ICTD } \\
\text { Falmouth Scientific } \\
\text { Product line } \\
\text { continued by } \\
\text { Teledyne RD } \\
\text { Instruments }\end{array}$ & $\begin{array}{l}1995 \\
\text { to } \\
1999\end{array}$ & $\begin{array}{l}\text { Sensor: } \\
\text { Range: } \\
\text { Accuracy: } \\
\text { Stability: } \\
\text { Resolution: } \\
\text { Response: }\end{array}$ & $\begin{array}{l}\text { Precision-machined } \mathrm{Si} \\
0 \text { to } 7000 \text { dbar } \\
\pm 0.01 \% \text { f.s. } \\
\pm 0.002 \% \text { f.s. } \text { month }^{-1} \\
0.0004 \% \text { f.s. } \\
25 \mathrm{~ms}\end{array}$ & $\begin{array}{l}\text { Platinum Thermistor } \\
-2 \text { to } 35^{\circ} \mathrm{C} \\
\pm 0.002{ }^{\circ} \mathrm{C} \\
\pm 0.0002{ }^{\circ} \mathrm{Cmonth}^{-1} \\
0.00005^{\circ} \mathrm{C} \\
150 \mathrm{~ms}\end{array}$ & $\begin{array}{l}\text { Inductive cell } \\
1 \text { to } 70 \mathrm{mS} \mathrm{cm}^{-1} \\
\pm 0.002 \mathrm{mS} \mathrm{cm}^{-1} \\
\pm 0.0005 \mathrm{mS} \mathrm{cm}^{-1} \text { month }^{-1} \\
0.0001 \mathrm{mS} \mathrm{cm}^{-1} \\
5 \mathrm{~cm}^{-1} 1 \mathrm{~m} \mathrm{~s}^{-1}\end{array}$ \\
\hline $\begin{array}{l}\text { SBE911plus } \\
\text { Sea-Bird } \\
\text { Electronics }\end{array}$ & $\begin{array}{l}1992 \\
\text { to } \\
\text { present }\end{array}$ & $\begin{array}{l}\text { Sensor: } \\
\text { Range: } \\
\text { Accuracy: } \\
\text { Stability: } \\
\text { Resolution: } \\
\text { Response: }\end{array}$ & $\begin{array}{l}\text { Paroscientific Digiquartz } \\
0 \text { to } 6800 \text { dbar } \\
\pm 0.015 \% \text { f.s. } \\
\pm 0.0015 \% \text { f.s. } \text { month }^{-1} \\
0.001 \% \text { f.s. } \\
15 \mathrm{~ms}\end{array}$ & $\begin{array}{l}\text { Thermistor } \\
-5 \text { to } 35^{\circ} \mathrm{C} \\
\pm 0.001{ }^{\circ} \mathrm{C} \\
\pm 0.0002{ }^{\circ} \mathrm{Cmonth}^{-1} \\
0.0002{ }^{\circ} \mathrm{C} \\
65 \mathrm{~ms}\end{array}$ & $\begin{array}{l}\text { Three-electrode cell } \\
1 \text { to } 70 \mathrm{mS} \mathrm{cm}^{-1} \\
\pm 0.003 \mathrm{mS} \mathrm{cm}^{-1} \\
\pm 0.003 \mathrm{mS} \mathrm{cm}^{-1} \mathrm{month}^{-1} \\
0.00001 \mathrm{mS} \mathrm{cm}^{-1} \\
65 \mathrm{~ms}\end{array}$ \\
\hline $\begin{array}{l}\text { SBE19 } \\
\text { self-recording } \\
\text { Sea-Bird } \\
\text { Electronics }\end{array}$ & $\begin{array}{l}1997 \\
\text { to } \\
2003\end{array}$ & $\begin{array}{l}\text { Sensor: } \\
\text { Range: } \\
\text { Accuracy: } \\
\text { Stability: } \\
\text { Resolution: } \\
\text { Response: }\end{array}$ & $\begin{array}{l}\text { Strain gauge } \\
0 \text { to } 10000 \text { psi } \\
0.15 \% \text { f.s. } \\
- \\
0.015 \% \text { f.s. } \\
-\end{array}$ & $\begin{array}{l}\text { Thermistor } \\
-5 \text { to } 35^{\circ} \mathrm{C} \\
\pm 0.01{ }^{\circ} \mathrm{C} \\
- \\
0.001^{\circ} \mathrm{C} \\
-\end{array}$ & $\begin{array}{l}\text { Three-electrode cell } \\
0 \text { to } 70 \mathrm{mS} \mathrm{cm}^{-1} \\
\pm 0.01 \mathrm{mS} \mathrm{cm}^{-1} \\
- \\
0.001 \mathrm{mS} \mathrm{cm}^{-1} \\
-\end{array}$ \\
\hline
\end{tabular}

* operated by guest institutes; f.s.: full scale; -: no data.

\subsection{Water samplers}

With the exception of the self-contained probe SBE19, all CTDs were used in combination with a water sampler. The Neil Brown Mark IIIB was combined with a General Oceanics (GO) rosette. The GO rosette required taking numerous samples for checking conductivity measurements and also using reversing thermometers to verify that bottles were closed at the desired depth. The reason is that GO used a non robust mechanical release to close the water samplers. Often the mechanics failed, which resulted in the closure of two or more samplers during one release command. This problem was solved with the introduction of the ICTD because Falmouth Scientific (FSI) supplied a new release module which confirmed successful or non-successful release commands.
Later the complete GO hardware was replaced by a release unit from FSI, which used a release system similar to the one used in the SBE32 carousel water sampler, confirming the release command and thus making water sampling more reliable. This positive development (1992 onwards) affected the in situ calibration, rendering the usage of reversing thermometers obsolete.

\subsection{In situ calibration}

Laboratory calibration of instruments (see Sect. 2.2) is crucial to maintain the sensors and obtain comparable results. It is not sufficient, however to anticipate how a sensor behaves at sea under tough environmental conditions, especially dur- 
ing deep casts. Also sensor drift is not necessarily a continuous process. For this purpose in situ calibrations are essential.

Temperature: the Mark IIIB CTD was equipped with one temperature (and one conductivity) sensor only. Therefore reversing thermometers attached to the bottles of the water sampler had to be used to verify the quality of the temperature data. The Triton ICTD was equipped with a redundant temperature sensor which allowed for much better control of temperature data than the reversing thermometers. Lastly, the SBE911plus features double sensors, both for temperature and conductivity measurements, allowing the plotting of the difference between both sensors versus depth, which eases identification of individual sensor problems and pressure effects. Additionally, a SBE35 Deep Ocean Standards Thermometer was attached to the water sampler, recording the temperature every time a water sample was taken. However, the comparison of the CTD and SBE3plus temperature values to the SBE35 temperature values is only possible if the water temperature is relatively stable, i.e., if the values do not vary much.

Conductivity: for the in situ calibration of the conductivity sensor (Mark IIIB and Triton ICTD) or the conductivity double sensors (SBE911plus), water samples were taken and measured on board with the laboratory salinometer Guildline Autosal 8400a/b and, from 2010, with the OPS (see Sect. 2.6). The samples were taken from deep $(>3000 \mathrm{~m})$ and shallow depths (ca. 500-1000 m) regularly during the CTD deployments in order to reveal pressure effects of the conductivity sensor and its temporal shift.

\subsection{Data processing}

The data processing procedures were substantially dependent on the development of the CTD and the computer generation. In 1983, CTD data were recorded on nine-track magnetic tape. The station data (location, water depth, date, and time) were noted on a sheet of paper. An HP 9825B computer was used to visualize the temperature and salinity profile on a connected plotter. The data processing was performed at the institute. Due to the fact that, for safety reasons, the magnetic tapes always came back to Bremerhaven with Polarstern, the data processing often only started several months after the end of the cruise leg. Later (around 1986), EG\&G - who took over the production of the Mark IIIB in 1984 - transferred the FORTRAN code of the data acquisition and processing routines of the Woods Hole Oceanographic Institution (WHOI) (Millard and Yang, 1993) for use on PCs. A similar software package was also provided for the ICTD from Falmouth Scientific. This made the data acquisition and visualization as well as the transfer of raw data to AWI much easier. The substructure of the software for applying the SIO calibration came from R. Williams and F. Delahoyde (personal communication, 1990).

Sea-Bird Electronics provided the data acquisition software SEASAVE and developed a package especially for their pumped CTD SBE911plus, SBE DataProcessing. This software became the primary tool for CTD data processing at the AWI. Also, the raw data were routinely stored on the onboard computer and transferred to the AWI in an automatic workflow.

The data processing workflow can be divided into four parts, as explained in the following subsections:

\subsubsection{Data cropping and handling}

Data recording started before the actual profile began (starting point at the lowering of the CTD/rosette to the water surface). Thus, one of the first tasks was the truncation of the unused beginning (the depth of the first "used" data point depends on the wave height). Converting the raw file into readable engineering units was the next step as well as the separation between the down- and up-cast, if both had been saved in one file. Afterwards, the station information was added to the data file. In the past this information was manually edited from handwritten station protocols. With the inauguration of the DSHIP electronic station book (http://www.werum.de/ en/platforms/DSHIP.jsp) station details were directly merged with the CTD data.

\subsubsection{Correction of measurement errors}

Physical properties of the sensors and environmental influences on them, as well as disturbances of the data transmission between sensors and recording units on deck, can create measurement errors. These were reduced using suitable software in the following ways:

- Spikes: spikes in the pressure measurements resulting, for example, from winch cable or slip ring problems, were removed. The procedure is called "par" in SeaBird's SBEDataProcessing software package.

- Response time/time lag correction: salinity was computed from conductivity, temperature, and pressure. The response time of a temperature sensor, however, is higher than the response time of the pressure and conductivity sensors. If left uncorrected, this would result in salinity spikes in layers with strong gradients. A precise correction for this time lag would require a constant lowering speed of the CTD, which is not possible on a moving ship. Sea-Bird solved this problem by pumping water with a constant speed through the temperature and conductivity sensors. For Mark IIIB and ICTD the time lag was adjusted/corrected by minimizing the salinity spikes and evaluated visually based on profile plots.

- Pressure hysteresis: Mark IIIB strain gauge pressure sensors did not respond linearly to increasing pressure and additionally exhibited a lagged response during decreasing pressure. This behavior also depended on the maximum pressure. A laboratory calibration (see 
Sect. 2.2) revealed this behavior and provided the coefficients for the software to apply the correction. However, the software was rather tricky because it only used hysteresis correction for the maximum pressure (6500 dbar) to calculate the correction for all profile depths (R. Williams and F. Delahoyde, personal communication, 1990). A second calibration up to $1500 \mathrm{dbar}$ was recorded to verify the algorithm of the software. ICTDs did not show this behavior and only a minor offset had to be applied. A Digiquatz ${ }^{\circledR}$ pressure sensor from Paroscientific was used in the SBE911plus. This sensor was stable, operating without hysteresis, so no frequent calibration was necessary.

- Compression and thermal effect: the ICTD with its inductive conductivity sensor had a known pressure dependency (compression of the cell ceramics), which was corrected by SBE software. In addition a thermal mass correction ${ }^{3}$ was applied for the ICTD and the SBE911plus conductivity cell.

\subsubsection{Creation of a uniform profile}

- Monotonic increasing pressure: as a ship is always pitching and rolling, the constant lowering speed of the winch is superimposed by the ships motion. Rejecting all records with pressure reversals is thus one of the standard procedures in CTD data processing, and was also applied on Polarstern data.

- Averaging: the SBE911plus CTD sampled with a frequency of $24 \mathrm{~Hz}$. A typical lowering speed of $0.8 \mathrm{~m} \mathrm{~s}^{-1}$ resulted in a vertical resolution of around $3 \mathrm{~cm}$. This sample rate was needed to apply the time lag correction reliably and also to guarantee that, although lots of records were rejected, a monotonic increasing pressure record could be created. In the end, the profile was smoothed by averaging on $1 \mathrm{dbar}$ levels (i.e., $P$, $T$ and $C$ were averaged between $\geq 1.5$ and $<2.5$; between $\geq 2.5$ and $<3.5 \mathrm{dbar}$, and so on). As this will not necessarily result in an averaged pressure record for $2.0,3.0, \ldots$ dbar (more probable in 1.97, 3.05, .. dbar), a linear interpolation was applied for temperature and conductivity, so that the values could be centered on exactly $2.0,3.0, \ldots$ dbar. Only after this procedure was the salinity calculated.

\subsubsection{Final correction and validation}

- Drift, stability, and pressure dependency: the physical characteristics of sensors change continuously through

\footnotetext{
${ }^{3} \mathrm{~A}$ cell which is lowered from a warm into a cold layer needs some time to reach the same temperature as the water. That means that heat from the cell is transferred into the water and the water becomes slightly warmer resulting in higher conductivity.
}

time. This behavior becomes visible as a slight change of their sensitivity. The order of this change is given by the manufacturer ("stability"; see Table 1). But the stability depends on the environmental conditions as well. For example, by conducting many deep casts, an additional sensor drift could be induced due to an a priori unknown pressure dependency. Also marine growth inside the conductivity cell will change the drift. Additionally, Polarstern CTDs were deployed even in rough weather conditions meaning that the instruments could bump against the ship's hull or experienced hard impacts on deck. These events could result in a visible step-like change. The station log sheets (which essentially contain descriptions of special occurrences), the pre-, post-, and in situ calibration helped to reconstruct the history of a sensor during a cruise and to identify which $T-C$ sensor pair should be used. General plotting software can be used to visualize the in situ calibrations versus pressure or versus time to investigate the dependency (drift), and to then apply and verify the corrections.

- Validation: all profiles were imported into Ocean Data View (Schlitzer, 2015) which provides various plots (profiles, scatter, and sections) for a visual inspection. When a suspicious profile was found, the processing steps mentioned above were repeated from the necessary level onwards. Additionally, these profiles were compared to profiles from previous cruises. The working database included a number of regularly repeated transects, which allowed consistency checks and quality confirmation.

\subsection{OPTIMARE precision salinometer}

Since 1985, laboratory measurements of salinity have been conducted on water samples taken with a rosette/carousel multi-bottle sampler to cross-validate the in situ CTD measurements. These laboratory salinity measurements were taken with salinometers. Salinometer measurements have several advantages compared to in situ measurements. For one, the salinometer measurements are controlled directly with the primary standard International Association for the Physical Sciences of the Oceans (IAPSO) Standard Seawater, which means that the salinometer is closer to the primary standard. Furthermore, the SBE911plus salinity sensor (SBE4) is calibrated using a bath of nearly constant salinity and varying temperatures, leading to different conductivities. The salinometer, however, is calibrated by using different salt concentrations, which makes the salinometer measurements more accurate for salinities varying around the typical openocean value of 35 PSU.

A Guildline Autosal 8400a/b salinometer was in use until 2010. Since then, it has been replaced by a new laboratory salinometer, the OPS developed by AWI scientists and en- 


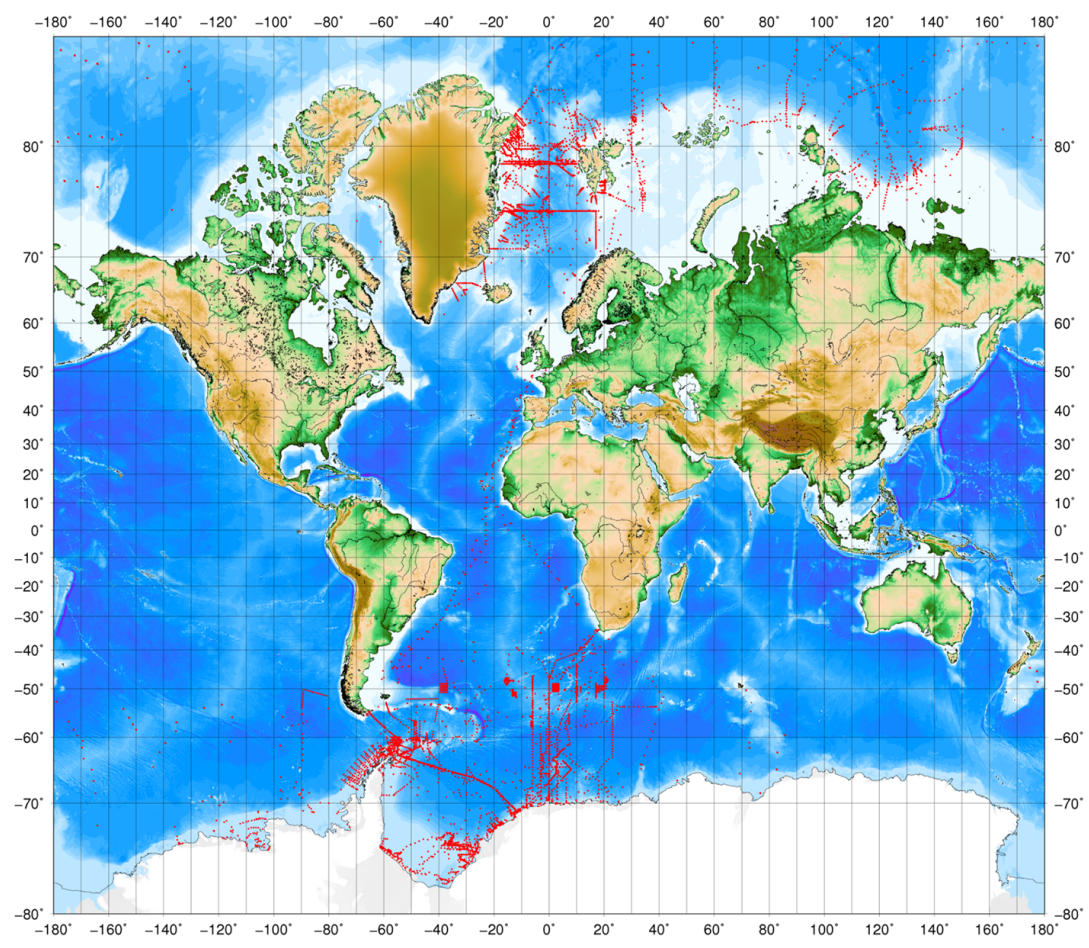

R.V. Polarstern

$22.11 .1983-14.02 .2016$ CTD casts
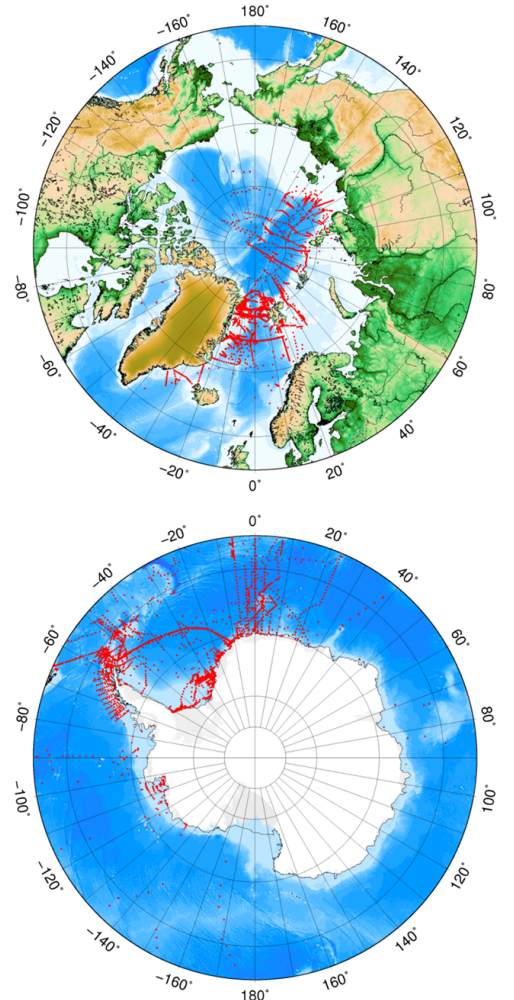

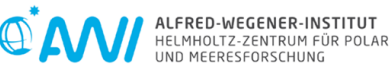

Figure 3. Map showing all sites where CTD data were collected with Polarstern from 1983 to 2016.

gineers and manufactured by OPTIMARE 4 (Budéus, 2011, 2015). The highly accurate OPS lab measurements have been in use since June 2010 to cross-calibrate in situ salinity data measured by the CTD. As a result, beginning with campaign ANT-XXV/1 (2010/06) the accuracy of the salinity measurements improved tremendously and the resulting data sets are of the highest quality possible for these kinds of measurements.

\section{Resulting data sets}

In total 131 data sets (1 data set per cruise leg) containing data from 10063 CTD casts have been produced on Polarstern in the course of 33 years (22 November 1983 to 14 February 2016, Fig. 3) and are archived in the PANGAEA (Data Publisher for Earth and Environmental Science, www.pangaea.de) database. The data sets can be accessed at http://doi.pangaea.de/10.1594/PANGAEA.860066 (Rohardt et al., 2016). This link leads to the central page which contains all meta-information of the respective cruise legs (name of leg, start/end, area, link to cruise report), the number of CTD casts, the CTD type used, the overall quality

\footnotetext{
${ }^{4}$ Optimare Sensorsysteme GmbH \& Co. KG
}

of the data, the link to a map displaying all CTD stations, and the link to the data set of the specific leg.

When clicking on the link to a data set of one cruise leg (see, e.g., Rohardt, 2010c, doi:10.1594/PANGAEA.733664) the data set page contains metadata, a Google map of all sample sites, and on the bottom the actual data. On the top of the page the citation of the data set is given, followed by the citation of the respective cruise report (if available). The CTD type used is indicated in the "Method" column of the Parameter(s) overview table of the page. The data table opens by clicking on "View dataset as html". Here, the position, date/time (at maximum depth) of sampling, and the water depth precede the actual data. The "Elevation" is the bathymetric depth relative to sea level and is therefore negative. It can be used, for example, to extract information on how close to the seafloor the CTD measurements ended (comparing water depth of the last measurement with the elevation). The "Number of observations" is the number of measurements included in one averaging step (see Sect. 2.5.3). With programs like Ocean Data View (Schlitzer, 2015) and Pan2Applic (Sieger and Grobe, 2005) the data can be visualized easily (for more information, see https://wiki.pangaea. de/wiki/ODV). With respect to CTD type, the 131 data sets are composed of 27 legs with Mark IIIB CTD data, 4 legs with ICTD data, 2 legs with ME-OTS data, 5 legs with data 
Table 2. Quality code details for Polarstern CTD data sets in PANGAEA.

\begin{tabular}{llll}
\hline $\begin{array}{l}\text { Quality } \\
\text { code }\end{array}$ & Description & Comment & $\begin{array}{l}\text { Possible use } \\
\text { (example) }\end{array}$ \\
\hline A & $\begin{array}{l}\text { Highest accuracy and } \\
\text { quality possible }\end{array}$ & $\begin{array}{l}\text { SBE911plus with double sensors; } \\
\text { pre- and post-calibration applied, } \\
\text { salinity samples measured during the cruise }\end{array}$ & $\begin{array}{l}\text { Investigate long-term changes of } \\
\text { temperature and salinity }\end{array}$ \\
\hline B & $\begin{array}{l}\text { Within WOCE accuracy } \\
\text { and quality limits }\end{array}$ & $\begin{array}{l}\text { SBE911plus without double sensors, Mark IIIB } \\
\text { or ICTD; pre- and post-calibration applied, } \\
\text { salinity samples measured during the cruise }\end{array}$ & Investigate long-term changes of temperature \\
\hline C & $\begin{array}{l}\text { Accuracy and quality } \\
\text { of the data is rather } \\
\text { low or unknown }\end{array}$ & $\begin{array}{l}\text { Without pre- and post-calibration, } \\
\text { no salinity samples, or no detailed } \\
\text { documentation of data processing }\end{array}$ & Hydrography for the specific cruise only \\
& & &
\end{tabular}

from a Sea-Bird self-recording CTD, and 93 legs with the SBE911plus. Most of the data sets (1992 onwards) contain additional measurements of oxygen concentration, light transmission/attenuation, and/or chlorophyll fluorescence.

\subsection{Several remarks on the best use of Polarstern CTD data}

- If available, the respective cruise report is linked to the data set. It contains valuable information on the cruise itinerary, the scientific purpose, and on the quality of the CTD data or the calibration applied.

- We defined a column on the overall quality of the data of each leg in Rohardt et al. (2016) called "Quality code". Here we use flags "A", "B", and "C" to classify the data with A being high quality data (see Table 2 for details).

- In general, the number of decimals in the data sets is at least $n+1$, with $n$ being the last significant decimal. This was done deliberately, as we experienced that for calculations (in models), the actual (unrounded) number of the last significant decimal can be essential.

- You can search for specific parameters, regions, etc., in the data sets described here using the www.pangaea. de search engine and adding "PSctd". You can then define a geographic bounding box in the map (right side of search page) to search for specific regions (e.g., Arctic data) and press "apply". Or you can try "PSctd + parameter:oxygen" to get all data sets with oxygen measurements. We also added an overview in .xls format of these additional measurements at http://doi.pangaea.de/10.1594/PANGAEA.860066 (under "Further details") which contains information (where available) on whether or not these measurements were calibrated, and during which campaign which additional measurements were taken.

- To download several or all data sets at once, you can either use the Data Warehouse integrated into
PANGAEA, or you can use a program especially designed for this purpose called PanGet. Data Warehouse: $\log$ in to PANGAEA (or create an account) at www. pangaea.de, then search for "PSctd" (or, for example, "PSctd+ oxygen"). On the top right corner you can click on Data Warehouse (above the Google map). Here you can choose which parameters to download, followed by clicking on "Start Data Warehouse Query". Please be aware that downloading all files requires over 1.5 GB which might take some time to download. How to download files with PanGet is described at https: //wiki.pangaea.de/wiki/PanGet.

- A CTD file downloaded from PANGAEA can easily be imported into Ocean Data View (Schlitzer, 2015) using Pan2Applic (Sieger and Grobe, 2005). Open the downloaded file in Pan2Applic, click on "Convert $\Rightarrow$ Ocean Data View" and click "OK", then choose "Select data (2:)" and "Select geocode (3:)" and press "OK". The data are now loaded into ODV and you can, for example, visualize it with different modes at "View $\Rightarrow$ Layout templates".

- For a detailed geographical search of the available data we created a Google .kmz file containing all CTD casts. When clicking on a single cast, a small window opens up displaying metadata details and a link to the data in PANGAEA. The .kmz file can be found under "Further details" at http://doi.pangaea.de/10.1594/ PANGAEA.860066 or at http://hdl.handle.net/10013/ epic.50376.d001.

\section{Data availability}

All data are accessible via http://doi.pangaea.de/10.1594/ PANGAEA.860066. The data sets are freely available and can be directly downloaded. A moratorium is still in place for the latest campaign (PS96), but the data are available upon request. 

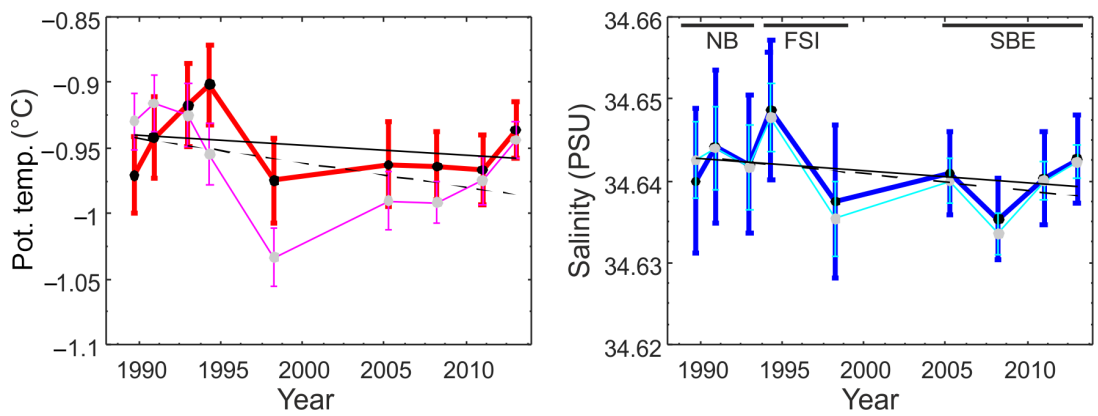

Figure 4. Mean potential temperature (left) and mean salinity (right) of the Weddell Sea Bottom Water calculated from nine repeated CTD sections at the tip of the Antarctic Peninsula (T. Kanzow, personal communication, 2016). The thin curves - magenta and cyan - include the seasonal effect. In the thick red and blue curves, the seasonal influence is eliminated. Linear regression lines are shown in black: dashed lines with seasonality included and solid lines with seasonality removed. The CTD type used is shown as follows: NB, Neil Brown; FSI, Triton ICTD; and SBE, SBE911plus.

\section{Conclusions}

Even small changes in sea-water density might affect vertical layering of water masses in the ocean (Olbers et al., 2012). Especially at low temperatures, small salinity changes affect the density much more than temperature changes of the same order (Schott et al., 1993). Therefore precise salinity measurements are needed, especially in polar regions. Based on repeated measurements, long-term changes of water mass properties can be studied (see, e.g., Fahrbach et al., 2011). Figure 4 shows the mean potential temperature and mean salinity of the Weddell Sea Bottom Water from nine repeated CTD sections at the tip of the Antarctic Peninsula. While the temperature shows similar errors of the mean, the errors of the mean salinity have become much smaller since 2005, which coincides with the use of the SBE911plus CTD on Polarstern. This illustrates clearly that when analyzing longterm trends from CTD data, the CTD type has to be taken into account. Additionally, in situ onboard calibration, regular servicing and laboratory calibration, data processing procedures, and experienced operators are required for precise data. CTD data therefore are of the highest value only if they come with proper documentation. One ambitious project analyzing and describing the complete set of available Arctic CTD data in respect to quality is currently taking place and will hopefully be published soon (Behrendt et al., 2017).

Competing interests. The authors declare that they have no conflict of interest.

Acknowledgements. We would like to thank Wolfgang Cohrs for creating Fig. 3. Many thanks to the numerous students who joined the CTD watches. Without their help it would have been impossible to run CTDs in $24 \mathrm{~h}$ shifts. Sometimes it was necessary to use external CTD operators and we thus appreciate the help of the Bremerhaven firms OPTIMARE and FIELAX, who both did an excellent job. Well-prepared instruments are the foundation for precise measurements. We therefore extend our gratitude to all CTD technicians, first and foremost to Ekkehard "Ekki" Schütt, who was not only dedicated to his job but also had the uncanny talent of identifying impending failures before they happened. Many thanks also to our current technicians: Matthias Monsees, Rainer Graupner and Carina Engicht. Last but not least, we are indebted to the crew of R/V Polarstern. During these 33 years crew members changed, of course, but it was always an exceptional team determined to make every campaign a success. Additionally, we would like to also thank the German Bundesministerium für Bildung und Forschung (BMBF) for placing Polarstern at the disposal of science. This ship has enabled polar research in conditions with up to force 8 winds. It even allowed for CTD transects during extremely heavy sea ice conditions with the ships powerful thrusters keeping the water surface ice-free while getting the CTD/rosette into the sea and back on deck safely.

The article processing charges for this open-access publication were covered by a Research Centre of the Helmholtz Association.

Edited by: G. M. R. Manzella

Reviewed by: L. Rickards and E. Viazilov

\section{References}

Behrendt, A., Sumata, H., Rabe, B., and Schauer, U.: A comprehensive, quality-controlled and up-to-date data set of Arctic Ocean temperature and salinity, in preparation, 2017.

Brown, N.: The history of salinometers and CTD Sensor:systems, Oceanus, 34, 61-66, 1991.

Budéus, G. T.: Bringing laboratory salinometry to modern standards, Sea Technology Magazine, 52, 45-48, http://www. sea-technology.com/features/2011/1211/salinometry.php, last access: 10 January 2017, 2011.

Budéus, G. T.: FAQ to Optimare Precision Salinometer (OPS), Alfred Wegener Institute, Helmholtz Center for Polar and Marine Research, Bremerhaven, hdl:10013/epic.49362.d001, 2015. 
Driemel, A., Loose, B., Grobe, H., Sieger, R., and KönigLanglo, G.: 30 years of upper air soundings on board of R/V POLARSTERN, Earth Syst. Sci. Data, 8, 213-220, doi:10.5194/essd-8-213-2016, 2016.

Fahrbach, E., Hoppema, M., Rohardt, G., Boebel, O., Klatt, O., and Wisotzki, A.: Warming of deep Water masses along the Greenwich meridian on decadal time scales: The Weddell gyre as a heat buffer, Deep-Sea Res. Pt. II, 58, 2509-2523, doi:10.1016/j.dsr2.2011.06.007, 2011.

Hales, S.: A Letter to the Rev. Dr. Hales, F. R. S. from Captain Henry Ellis, F. R. S. Dated Jan. 7, 1750-51, at Cape Monte Africa, Ship Earl of Hallifax, Philosophical Transactions, 47, 211-216, 1751.

Millard, R. C. and Yang, K.: CTD Calibration and Processing Methods used at Woods Hole Oceanographic Institution, Woods Hole Oceanographic Institution, Technical Report, WHOI-9344, doi:10.1575/1912/638, 1993.

Olbers, D., Willenbrand, J., and Eden, C.: Ocean Dynamics, Springer Berlin Heidelberg, 703 pp., doi:10.1007/978-3-64223450-7, 2012.

Rohardt, G.: Physical oceanography during POLARSTERN cruise ANT-II/3, Alfred Wegener Institute, Helmholtz Center for Polar and Marine Research, Bremerhaven, doi:10.1594/PANGAEA.734969, 2010a.

Rohardt, G.: Physical oceanography during POLARSTERN cruise ANT-II/4, Alfred Wegener Institute, Helmholtz Center for Polar and Marine Research, Bremerhaven, doi:10.1594/PANGAEA.734972, 2010b.

Rohardt, G.: Physical oceanography during POLARSTERN cruise ANT-XXII/3, Alfred Wegener Institute, Helmholtz Center for Polar and Marine Research, Bremerhaven, doi:10.1594/PANGAEA.733664, 2010c.
Rohardt, G., Fahrbach, E., Beszczynska-Möller, A., Boetius, A., Brunßen, J., Budéus, G., Cisewski, B., Engbrodt R., Gauger, S., Geibert, W., Geprägs, P., Gerdes, D., Gersonde, R., Gordon, A. L., Hellmer, H. H., Isla, E., Jacobs, S. S., Janout, M., Jokat, W., Klages, M., Kuhn, G., Meincke, J., Ober, S., Østerhus, S., Peterson, R. G., Rabe, B., Rudels, B., Schauer, U., Schröder, M., Sildam, J., Soltwedel, T., Stangeew, E., Stein, M., Strass, V. H., Thiede, J., Tippenhauer, S., Veth, C., von Appen, W.-J., Weirig, M.-F., Wisotzki, A., Wolf-Gladrow, D. A., and Kanzow, T.: Physical oceanography on board of POLARSTERN (1983-11-22 to 2016-02-14), Alfred Wegener Institute, Helmholtz Center for Polar and Marine Research, Bremerhaven, doi:10.1594/PANGAEA.860066, 2016.

Schott, F., Visbeck, M., and Fischer, J.: Observations of vertical currents and convection in the Central Greenland Sea during the winter of 1988-1989, J. Geophys. Res., 98, 14401-14421, doi:10.1029/93JC00658, 1993.

Schlitzer, R.: Ocean Data View, http://odv.awi.de, last access: 3 December 2016, 2015.

Sieger, R. and Grobe, H.: Pan2Applic - a tool to convert and compile PANGAEA output files, doi:10.1594/PANGAEA.288115, 2005.

Stewart, R. H.: Introduction to Physical Oceanography, ORange: Grove Text Plus, 353 pp., 2009.

Warren, B. A.: Nansen-bottle stations at the Woods Hole Oceanographic Institution, Deep-Sea Res. Pt. I, 55, 379-395, doi:10.1016/j.dsr.2007.10.003, 2008. 